\title{
Assessment of nutrient entry pathways and dominating hydrological processes in lowland catchments
}

\author{
B. Schmalz, F. Tavares, and N. Fohrer \\ Dept. Hydrology and Water Resources Management, Ecology Centre, Kiel, Germany \\ Received: 15 January 2007 - Revised: 11 April 2007 - Accepted: 22 May 2007 - Published: 15 June 2007
}

\begin{abstract}
The achievement of a good water quality in all water bodies until 2015 is legally regulated since December 2000 for all European Union member states by the European Water Framework Directive (EU, 2000). The aim of this project is to detect nutrient entry pathways and to assess the dominating hydrological processes in complex mesoscale catchments.

The investigated Treene catchment is located in Northern Germany as a part of a lowland area. Sandy, loamy and peat soils are characteristic for this area. Land use is dominated by agriculture and pasture. Drainage changed the natural water balance. In a nested approach we examined two catchment areas: a) Treene catchment $517 \mathrm{~km}^{2}$, b) Kielstau catchment $50 \mathrm{~km}^{2}$. The nested approach assists to improve the process understanding by using data of different scales. Therefore these catchments serve not only as an example but the results are transferable to other lowland catchment areas.

In a first step the river basin scale model SWAT (Soil and Water Assessment Tool, Arnold et al., 1998) was used successfully to model the water balance. Furthermore the water quality was analysed to distinguish the impact of point and diffuse sources. The results show that the tributaries in the Kielstau catchment contribute high amounts of nutrients, mainly nitrate and ammonium. For the parameters nitrate, ammonium and phosphorus it was observed as a tendency that the annual loads were increasing along the river profile of the Kielstau.
\end{abstract}

\section{Introduction}

The achievement of a good water quality in all water bodies until 2015 is legally regulated since December 2000 for all European Union member states by the European Water
Framework Directive (EU, 2000). It sets up an examination of river catchments as spatial units and of interactions between water bodies and their environment.

Lowland areas are characterized by special properties like flat topography and low hydraulic gradients. Furthermore there is near-surface groundwater which results in a high groundwater - stream water interaction. Various river regulations, pumping stations and drainage systems like tile drainage and open ditches changed the natural water balance. Due to that a fast nutrient transport influences the instream water quality.

As nutrient entry pathways in rivers diffuse and punctual sources are thinkable (Pieterse et al., 2003; Meynendonckx et al., 2006; Wood et al., 2005). In catchment areas nutrient entries from agriculture (fertilizer, pesticides, animal husbandry in river vicinity) as well as from settlements (waste water, traffic routes) play a role. An assessment is feasible through measurements and with ecohydrological modelling in relation to water balance and quality.

The objective of this project is the assessment of the nutrient entry pathways and the dominating hydrological processes in a complex mesocale lowland catchment area. First results from measurements and ecohydrological modelling are presented.

\section{Investigation area}

The mesoscale investigation area is located in Northern Germany as a part of a lowland area of Schleswig-Holstein. Sandy, loamy and peat soils are characteristic for the catchment. Landuse is dominated by agriculture and pasture. The maximum height difference is $76 \mathrm{~m}$ for the entire area, and about $40 \mathrm{~m}$ for the eastern part. The precipitation is $872 \mathrm{~mm} / \mathrm{a}$ and the mean annual temperature $8.2^{\circ} \mathrm{C}$.

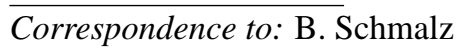

(bschmalz@hydrology.uni-kiel.de)

Published by Copernicus Publications on behalf of the European Geosciences Union. 


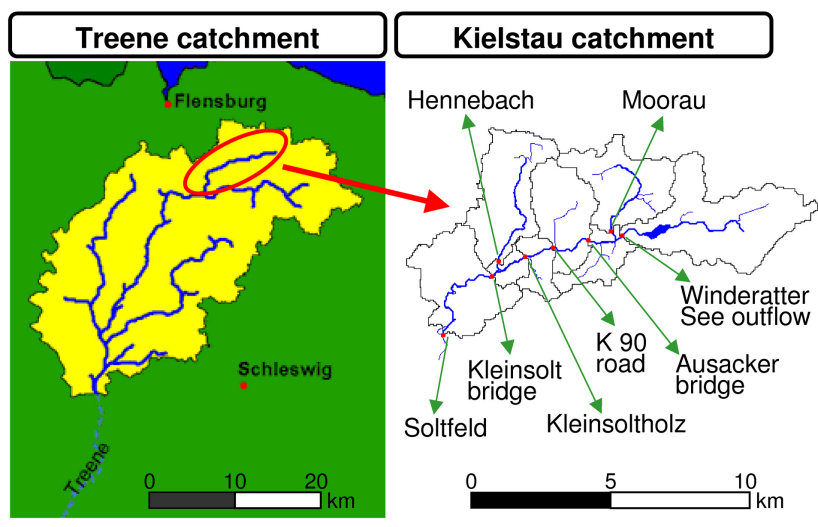

Fig. 1. Treene watershed (left; Dey, 2005) and its subcatchment Kielstau (right) with eight measuring stations and the model subcatchments.

In a nested approach we examine two catchment areas, which cover different scales:

a) Treene catchment $517 \mathrm{~km}^{2}, 60 \mathrm{~km}$ river length,

b) Kielstau catchment $50 \mathrm{~km}^{2}, 11 \mathrm{~km}$ river length

From the Treene catchment only that area without tide influence was considered.

The river Kielstau has its origin in the lake Winderatter See and has two important tributaries from the north, the Moorau and the Hennebach (Fig. 1). In addition various smaller tributaries and water from drainage pipes and open ditches flow into the Kielstau. The drained fraction of agricultural area in the Kielstau catchment is estimated 38\% (Fohrer et al., 2007). One wastewater treatment plant is situated at the beginning of the Moorau, another three are located in the vicinity of the Hennebach.

\section{Methods}

Measured and investigated data form the basis for the analysis and modelling. In measurement campaigns discharge and water quality were measured weekly from April 2005 till March 2006 at eight stations along the river profile of the river Kielstau and the two tributaries Moorau and Hennebach. The first station is situated circa $700 \mathrm{~m}$ from the lake outflow, the last station is gauge Soltfeld at the catchment outlet. Temperature, $\mathrm{pH}$, electrical conductivity, oxygen, $\mathrm{NH}_{4}, \mathrm{NO}_{3}, \mathrm{PO}_{4}$, Ptot, $\mathrm{Cl}$ and $\mathrm{SO}_{4}$ were analysed in field and lab.

There are two steps to tackle the project goals:

1. Ecohydrological modelling: The river basin model SWAT (Soil and Water Assessment Tool, Version AVSWAT2000, Arnold et al., 1998) was used in order to reproduce the water balance in these complex hydrologic catchment areas. SWAT is a semi-distributed, process oriented model for simulating water, nutrient and pesticide transport. Simulations are conducted for mesoscale catchments and their Hydrological Response Units (HRU; hydrotopes). The Treene model is based on data (1984-2000) from eight gauges, the Kielstau model on data from 1986-2005. Both models are based on data of own measuring campaigns and also from German authorities and institutions like Landesamt für Natur- und Umwelt des Landes SchleswigHolstein (LANU-SH), Deutscher Wetterdienst (DWD), Deutsches Zentrum für Luft- und Raumfahrt (DLR) and Staatliches Umweltamt in Schleswig (StUA-Schleswig) (see in detail in Dey (2004) and Tavares (2006)). Both models are used at daily steps.

2. Assessment: Water quality data and calculated loads in the Kielstau catchment were assessed in a detailed analysis. A general classification was conducted using the "LAWA procedure for the chemical classification of water bodies" (LAWA, 1998). In this paper we focus on the $\mathrm{N}$ and $\mathrm{P}$ components.

\section{Results}

\subsection{Ecohydrological modelling}

The ecohydrological modelling with SWAT was conducted by dividing the Treene catchment into 681 hydrotopes and 58 subcatchments (Dey, 2004), and the Kielstau catchment into 117 hydrotopes and 8 subcatchments. First modelling runs dealed with problems in simulating the stream flow correctly. They showed an underestimation of measured high winter discharge peaks, early response discharges in the late summer periods peaks and an overestimation of base flow mainly during the summer. Thus the modelled discharge dynamic was too small. According to the conditions in this lowland catchments several options were taken into consideration referring to the groundwater storage and drainage. For the Treene model 14\% drainage, an increase of the recession coefficient ALPHA_BF to 0.0286 (at the outlet) and a percolation time of two days for the hilly area were considered (Dey, 2004; Dey et al., 2004). For the Kielstau catchment a groundwater retention time of 50 days, an installation of ponds and wetlands as well as drainage (DDRAIN as $600 \mathrm{~mm}$ and TDRAIN as $24 \mathrm{~h}$ ) were included. Figure 2 shows as an example the stepwise calibration of the SWAT model for the Kielstau. Thereafter the modelling of the water balance with SWAT both of the Treene and of the Kielstau catchment areas showed a good correlation between measured and modelled discharges (Table 1, Figs. 3 and 4). The discharge dynamics were reproduced in a better way. 
Table 1. Performance of models relating to the catchment outlets (*Dey, 2004; Fohrer et al., 2006).

\begin{tabular}{lccc}
\hline & period & Nash-Sutcliffe index & correlation coefficient \\
\hline Treene calibration* & $1994-1995$ & 0.89 & 0.95 \\
Treene validation* & $1997-2000$ & 0.86 & 0.94 \\
Kielstau calibration & $01.01 .1990-31.12 .1999$ & 0.71 & 0.82 \\
Kielstau validation & $01.01 .2000-01.05 .2005$ & 0.63 & 0.75 \\
\hline
\end{tabular}

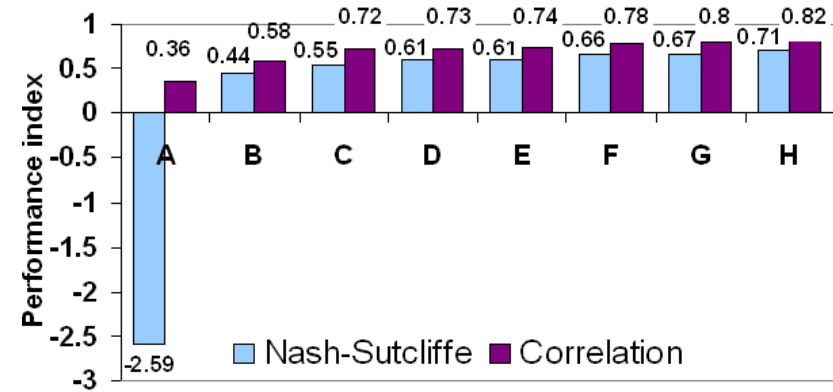

Fig. 2. Statistical development of model efficiency and correlation during the calibration steps. $\mathrm{A}=$ Base Model, $\mathrm{B}=$ GW_DELAY: $200 \mathrm{~d}, \mathrm{C}=$ GW_DELAY: $50 \mathrm{~d}$; GWQMN: $1250 \mathrm{~mm}$, $\mathrm{D}=$ GW_REVAP: $0.2, \mathrm{E}=\mathrm{REVAPMN}: 0.01 \mathrm{~mm}, \mathrm{~F}=$ Ponds $\&$ Wetlands, $\mathrm{G}=$ Drainage, $\mathrm{H}=\mathrm{CN} 2$ adjustments.

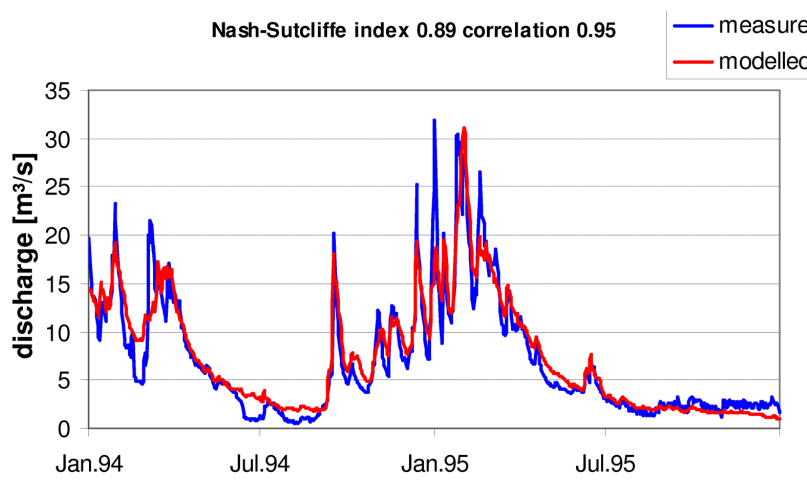

Fig. 3. Measured and modelled daily discharge at the catchment outlet of the Treene catchment during calibration (Dey, 2004).

\subsection{Water quality assessment}

Because of the complexity of processes in both hydrologic catchments we first looked in detail on the matter transport processes in the Kielstau catchment.

Along the river profile it was observed that the nitrogen concentrations were relatively small at the beginning of Kielstau, while the tributary Moorau supplied clearly increased NO3_N concentrations and a second tributary Hennebach increased NH4_N concentrations (Fig. 5). Possible sources are agriculture (fertilizer and a poultry farm in the middle of the Moorau) and/or wastewater treatment plants.

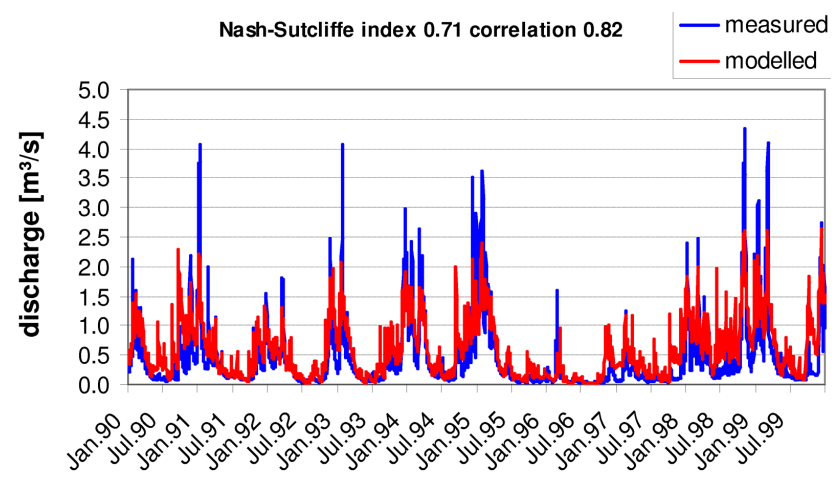

Fig. 4. Measured and modelled daily discharge at the catchment outlet of the Kielstau catchment during calibration.

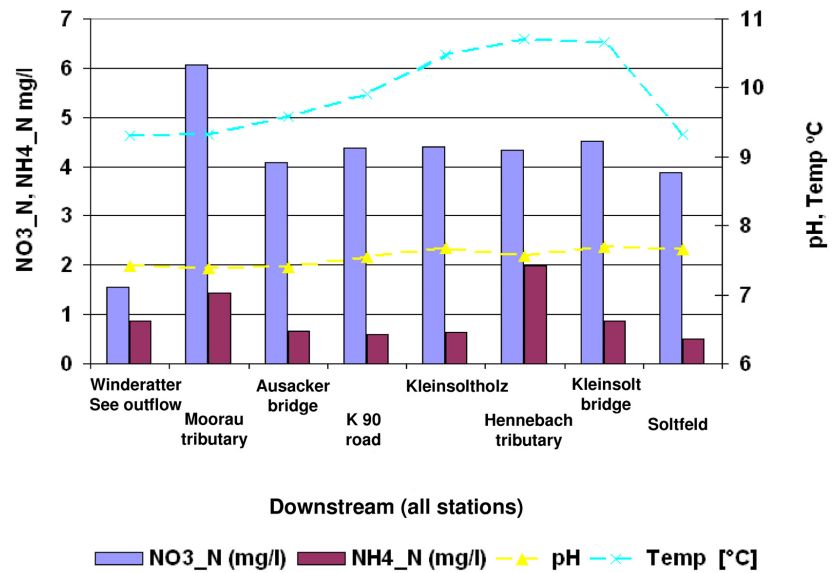

Fig. 5. Annual average concentrations of nitrate nitrogen $(\mathrm{mg} / \mathrm{l})$, ammonium nitrogen $(\mathrm{mg} / \mathrm{l}), \mathrm{pH}$ and water temperature $\left({ }^{\circ} \mathrm{C}\right)$ in all measurement stations investigated in the Kielstau. The tributaries are displayed in the river course where their waters join the Kielstau.

The measurements of phosphorus show opposite results (Fig. 6). The highest concentrations are at the beginning of the Kielstau and the water was then diluted in the river course. Probably the phosphate is set free from the sediment within the area of the lake at the beginning of the Kielstau. A current entry from the extensive agriculture is not so probable in that area deduced from field observations. From former times with intensive agriculture around the lake phosphate could be stored in the sediment. The lake water itself has no 


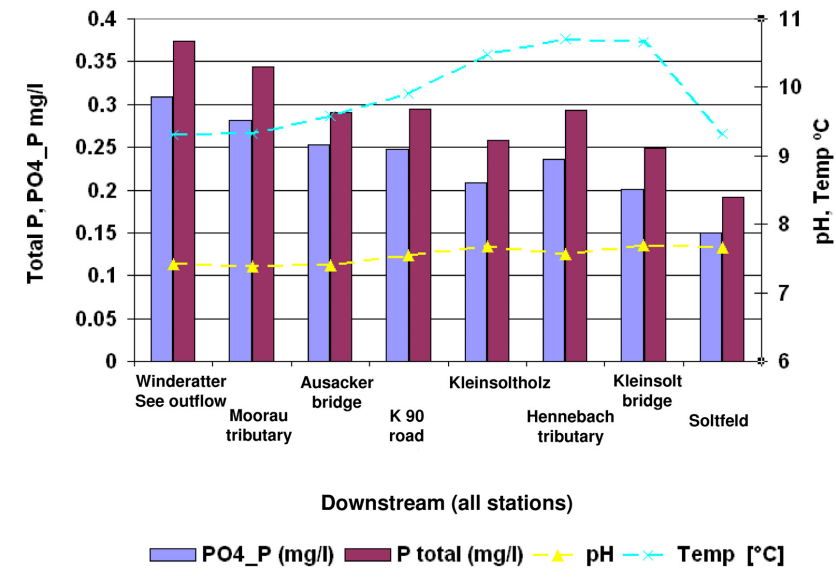

Fig. 6. Annual average concentrations of total phosphorus (mg/l), phosphate phosphorus (mg/l), $\mathrm{pH}$ and water temperature $\left({ }^{\circ} \mathrm{C}\right)$ in all measurement stations investigated in the Kielstau. The tributaries are displayed in the river course where their waters join the Kielstau.

high concentrations. The influence of a fen between the lake outlet and the first sampling point has to be clarified.

These observations were not only recognized by the annual values but could be confirmed by single observations in all four seasons. These observations allow the presumption that the major ammonium nitrogen and nitrate nitrogen nutrients are supplied by the Moorau tributary. The Hennebach revealed also an important role as ammonium nitrogen supplier.

Looking especially at the water quality of the Moorau and the close-by stations upstream and downstream in the main channel a general classification can be shown using the "LAWA procedure for the chemical classification of water bodies" (LAWA, 1998):

The LAWA classification in station Winderatter See outflow placed nitrate nitrogen concentrations within class I (zero burden) during the summer period. During winter the LAWA classification of significant burden (class II-III) was obtained. In one occasion (12.04.2005) the LAWA class enhanced burden (class III) was reached. The Moorau station presents a completely different situation, with the achievement of LAWA class III during most of the year. Throughout the summer period the significant burden classification was many times reached and in two occasions (12.04.2005 and 18.10.2005) class III-IV (great burden). In the downstream sampling station Ausacker bridge most of the year was classified as having a significant burden. This status was left once to reach zero burden class in 30.08.2005, in four occasions enhanced burden, and at 12.05.2005 the great burden class.

In the Winderatter See outflow station the ammonium nitrogen concentrations reached during the summer period the LAWA class IV (very great burden). In the winter period concentrations were mostly within LAWA class II (moderate burden). At Moorau station with a worse quality situation, in several occasions of the year, the LAWA class IV was reached. During the remaining period mostly LAWA class II was observed. The concentrations in Ausacker bridge station were predominantly within LAWA class II. However, in four occasions LAWA class IV was present and in other two occasions LAWA class III-IV was observed.

During most of the year the Winderatter See station presented phosphate phosphorus concentrations within LAWA class III-IV, being the class IV was achieved during the middle of July. In October LAWA class III were often and, in the beginning of May and November class II-III were reached. Most of the winter period was classified as having a moderate burden. At the Moorau station the concentrations were most of the year classified as LAWA class III. In two occasions (July and end of September) classification III-IV and once during December classification II were reached. The same classification tendency was revealed at measurement station Ausacker bridge. The LAWA classification for total phosphorus is in its majority similar to the classification tendency showed by phosphate phosphorus.

Looking in detail at the water quality at the catchment's outlet at Soltfeld the following classification was found: Most of the year nitrate nitrogen concentrations were classified within LAWA class II-III. In the winter period some occurrences of the class III were verified. For ammonium nitrogen the LAWA class IV was only reached once during the month of August. In one occasion (end of January) the class III-IV was observed. In the remaining period the concentrations were mostly distributed through the LAWA classes II and II-III. For phosphate phosphorus the class III-IV was never reached. From the middle of July until middle of August concentrations were found within LAWA class III and during most of the cold period the class II was reached.

\section{Loads}

For a better understanding of the tributaries influence on water quality nutrient loads were calculated by using observed discharge values.

Annual discharge in the tributaries is with about $2 \mathrm{~m}^{3} / \mathrm{s}$ clearly lower than in the main river (Figs. 7 and 8). Therefore the high concentrations resulted in lower loads, but were an essential addition to the stream loads. The loads of the Moorau were even higher than the loads at the lake outlet for the parameters nitrate nitrogen, ammonium nitrogen and both phosphorus parameters (Figs. 7 and 8). In all parameters a general increase in the loads is observed with increasing downstream distance in the main stream channel, except the small annual load from the Hennebach tributary.

To further investigate the influence of the tributaries it was calculated the load difference between the tributary downwards station and the load sum of tributary and station upwards from the tributary: The load sums of Winderatter See 


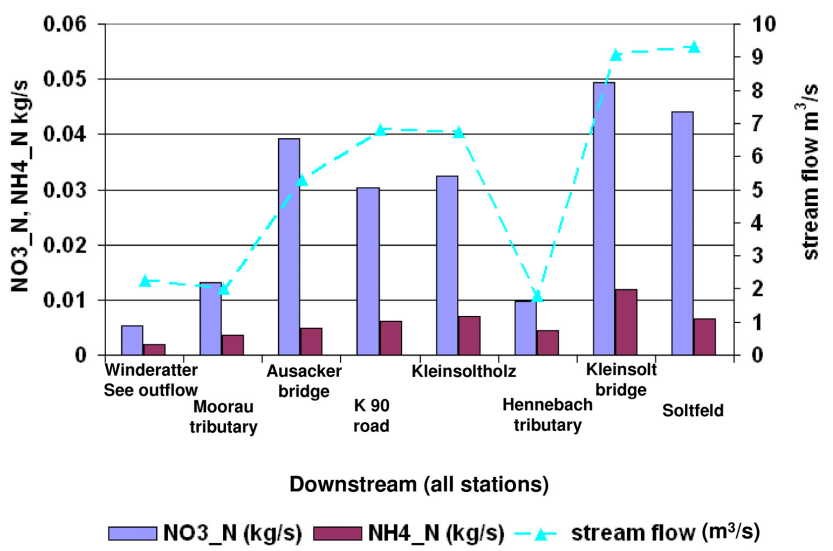

Fig. 7. Annual loads (kg/s) of nitrate nitrogen, ammonium nitrogen, and annual sum of runoff at all Kielstau stations and their tributaries.

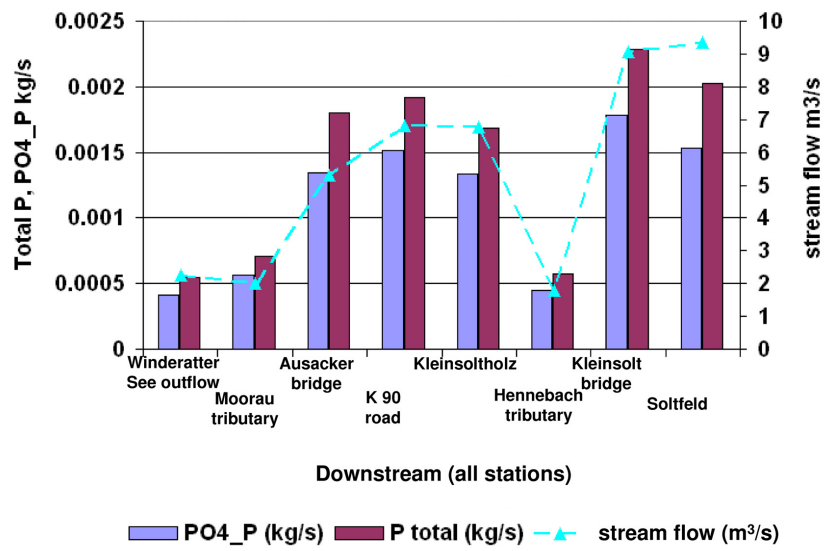

Fig. 8. Annual loads $(\mathrm{kg} / \mathrm{s})$ of total phosphorus, phosphate phosphorus and annual sum of runoff at all Kielstau stations and their tributaries.

outlet with Moorau tributary were always lower than the loads of Ausacker bridge which leads to the conclusion that the load increment in the downward point of the tributaries is mainly a consequence of joining one more branch to the main stream.

The nitrate nitrogen load observed in Kleinsolt bridge is only slightly higher as the sum of the loads observed at Kleinsoltholz and Hennebach tributary, but were nearly the same for ammonium nitrogen and both phosphorus parameters (Figs. 7 and 8).

\section{Conclusions}

The Treene catchment area and its subcatchment Kielstau in Northern Germany served as an example for lowland areas but the assessed results are however transferable to other lowland catchment areas. The nutrient entry pathways into rivers from diffuse and punctual sources and the dominat- ing hydrological processes were derived from measurements and ecohydrological modelling. First of all the water balance was successfully simulated with the ecohydrological mesoscale model SWAT. For the Treene it was achieved a Nash-Sutcliffe Index of 0.89 (correlation: 0.95), for the Kielstau catchment of $0.71(0.82)$.

Afterwards the entries from agriculture, wastewater treatment plants and sediment release were regarded and the influence of tributaries on the main channel water quality was determined. The results show that the tributaries in the Kielstau catchment contribute high amounts of nutrients mainly nitrate and ammonium. For the parameters nitrate, ammonium and phosphorus it was observed as a tendency that the annual loads were increasing along the river profile of the Kielstau. It can be noticed that both diffuse sources like nitrate entries from the agriculture and point sources such as wastewater treatment plants with mainly ammonium entries affect the water quality in the stream water.

The various measurements on different scales permit the understanding of transport processes in the investigation areas. A nested approach can be used to improve examinations on the catchment scale by using analyses of processes on local scale (subcatchments).

In the future the water quality and the point sources are to be considered within the ecohydrological model. Thus a better quantification of the agricultural entry pathways, a differentiation into point and diffuse sources with consideration of the management options and an evaluation of potential changes of management are assessable.

Edited by: K.-E. Lindenschmidt

Reviewed by: B. Guse and H. Nacken

\section{References}

Arnold, J.-G., Srinivasan, R., Muttiah, R. S., and Williams, J. R.: Large area hydrologic modelling and assessment, Part I: Model development, J. Am. Water Resour. As.,34(1), 73-89, 1998.

Dey, T.: Räumlich differenzierte Einzugsgebietsmodellierung für den tidefreien Bereich der Treene, Diplomarbeit im Fach Geographie, Ökologie-Zentrum Christian-AlbrechtsUniversität Kiel, 79p., http://www.hydrology.uni-kiel.de/lehre/ abschlussarbeiten/da_tdey.pdf, 2004.

Dey, T., Horn, A., Hörmann, G., and Fohrer, F.: Räumlich differenzierte Einzugsgebietsmodellierung am Beispiel des tidefreien Bereichs der Treene, In: Ludwig, R., Reichert, D. and Mauser, W. (eds): 7. Workshop zur großskaligen Modellierung in der Hydrologie: Neue methodische Ansätze zur Modellierung der Wasser- und Stoffumsätze in großen Einzugsgebieten, München, November 2003, 209p., Kassel University Press, 111-122, 2004.

Dey, T.: http://www.treenemodell.de/lage.htm, assess 08.01.2007, 2005.

EU: Richtlinie 2000/60/EG des Europäischen Parlaments und des Rates vom 23.10.2000 zur Schaffung eines Ordnungsrahmens für Maßnahmen der Gemeinschaft im Bereich der Wasserpolitik, Amtsblatt der Europäischen Gemeinschaften, 2000. 
Fohrer, N., Dey, T., Dobslaff, N., and Hörmann, G.: Räumlich differenzierte hydrologische Modellierung norddeutscher Tieflandeinzugsgebiete am Beispiel der Treene und der Stör, Ecosys. Suppl., 46, 107-120, 2006.

Fohrer, N., Schmalz, B., Tavares, F., and Golon, J.: Ansätze zur Integration von landwirtschaftlichen Dränagen in die Modellierung des Landschaftswasserhaushalts von mesoskaligen Tieflandeinzugsgebieten, Hydrologie \& Wasserbewirtschaftung, in print, 2007.

LAWA (Länderarbeitsgemeinschaft Wasser): Beurteilung der Wasserbeschaffenheit von Fließgewässern in der Bundesrepublik Deutschland, Chemische Gewässergüteklassifikation, Hrsg. Länderarbeitsgemeinschaft Wasser, Bearb. LAWA-Arbeitskreis "Zielvorgaben" in Zusammenarbeit mit LAWA-Arbeitskreis "Qualitative Hydrologie der Fließgewässer", Kulturbuchverlag Berlin, 69 S., 1998.
Meynendonckx, J., Heuvelmans, G., Muys, B., and Feyen, J.: Effects of watershed and riparian zone characteristics on nutrient concentrations in the River Scheldt Basin, Hydrol. Earth Syst. Sci., 10, 913-922, 2006, http://www.hydrol-earth-syst-sci.net/10/913/2006/.

Pieterse, N. M., Bleuten, W., and Jorgensen, S. E.: Contribution of point sources and diffuse sources to nitrogen and phosphorus loads in lowland river tributaries, J. Hydrol., 271, 213-225, 2003.

Tavares, F.: Continuous, spatially distributed, stream flow and quality assessment of a lowland catchment in Northern Germany, Masterarbeit im Studiengang "Environmental Management", Ökologie-Zentrum Christian-Albrechts-Universität Kiel, 134p., http://www.hydrology.uni-kiel.de/lehre/abschlussarbeiten/ msc_tavares.pdf, 2006.

Wood, F. L., Heathwaite, A. L., and Haygarth, P. M.: Evaluating diffuse and point phosphorus contributions to river transfers at different scales in the Taw catchment, Devon, UK, J. Hydrol., 304, 118-138, 2005. 